Brit. F. vener. Dis. (1973) 49, 427

\title{
Treponema pallidum haemagglutination assay in the routine serodiagnosis of treponemal disease
}

\author{
P. O'NEILL, R, W. WARNER, AND C. S. NICOL \\ From the Departments of Microbinlogy and Venereal Diseases, St. Thomas's Hospital, London S.E.1
}

A passive haemagglutination test using sheep erythrocytes sensitised with Treponema pallidum extract was introduced into syphilis serology by Rathlev (1965, 1967). Shortly afterwards, Tomizawa and Kasamatsu (1966) and Tomizawa, Kasamatsu, and Yamaya (1969) described a similar test, the Treponema pallidum haemagglutination assay (TPHA), and this was further developed as an automated quantitative microtechnique by Cox, Logan, and Norins (1969). An alternative technique in which sensitized fowl erythrocytes are used has been introduced by Sequeira (1973). Evaluation of the TPHA as a confirmatory test for syphilis has shown it to be about equal in sensitivity and specificity to the fluorescent treponemal antibody absorption (FTA-ABS) test, but much simpler to perform. (Logan and Cox, 1970; Garner, Backhouse, Daskalopoulos, and Walsh, 1972; Johnston, 1972).

The simplicity of the TPHA makes it attractive as a screening test. We describe here a microtechnique which is convenient for large-scale screening by TPHA and which we have used so far on over 17,000 sera. This report summarizes our experience with the technique, and discusses the place of the TPHA in the serodiagnosis of treponemal disease.

\section{Clinical material}

The sera examined were from three sources:

(a) Patients attending St. Thomas's Hospital Venereal Diseases Clinic. About one-third of these patients come from areas where yaws is endemic.

(b) Patients attending other departments of St. Thomas's and associated hospitals.

(c) Persons from the Teso and Ankole districts of Uganda. These sera were kindly provided by Dr. O. P. Arya of Makerere University.

Received for publication January 15, 1973

A preliminary account of this work was read at a Meeting of the M.S.S.V.D. at Glasgow in June, 1972

\section{Reagents and test procedures}

TPHA REAGENTS

These were obtained from two sources: Fuji-Zoki Company, Tokyo, Japan, and Wellcome Reagents Limited, Beckenham, Kent. Fuji-Zoki reagents comprise tanned formolized sheep erythrocytes sensitized with $T$. pallidum components, unsensitized control cells, and a diluent which, to minimize interference by heterophil and antigroup treponemal antibodies, includes soluble sheep erythrocyte, ox erythrocyte, and Reiter treponemal fractions. Wellcome Reagents TPHA antigen consists of $T$. pallidum sensitized turkey erythrocytes, unsensitized control cells, and a diluent containing no erythrocyte or Reiter treponemal components.

TPHA TEST PROCEDURES

Quantitative TPHA tests were performed by standard microprocedures in accordance with instructions provided by the manufacturers of the reagents. Qualitative screening was carried out by our own micromethod, described below.

\section{TPHA MICROMETHOD FOR LARGE-SCALE SCREENING}

This makes use of semiautomated microagglutination apparatus which was originated at St. Thomas's Hospital and is described in detail elsewhere (O'Neill, to be published). Sera to be tested are assembled in blocks of 120 and are not heat inactivated. The apparatus samples all 120 sera simultaneously (sample size $10 \mu \mathrm{l}$.), and dilutes them first in diluent and subsequently in an appropriately adjusted sensitized cell suspension, to give a final serum dilution of 1 in 80 . This takes about 2 minutes. The apparatus is then rinsed, and allowed to drain for 5 minutes before the next block of 120 sera is sampled. Trays of tests set up in this way are read after standing at room temperature for $2 \mathrm{hrs}$. Presumptive positives are then re-tested by the quantitative TPHA technique, using both sensitized and control cells, and tested by the FTA-ABS test.

\section{FTA-ABS TEST}

Reagents were obtained from Wellcome Reagents Limited. A microvolume semiautomated technique was used (O'Neill and Johnson, 1971). 
CONVENTIONAL TESTS FOR SYPHILIS

The cardiolipin Wassermann reaction, the Reiter protein complement-fixation test, and the VDRL slide test were performed using standard techniques. A modified carbon antigen VDRL slide test was also used, in conjunction with the semiautomated equipment referred to above. In this 120 VDRL tests are set up simultaneously in $9 \mathrm{~mm}$. clear glass circles on a $19 \times 10 \mathrm{~cm}$. PTFE coated glass slide. The slide carrying the 120 tests is rotated for 12 minutes on a VDRL rotator, and the tests are then lit from underneath and read by naked eye.

\section{Results}

(a) 1,000 sera from patients with suspected treponemal disease

Our first trial of the TPHA as a screening test was made on selected patients attending St. Thomas's Hospital Venereal Diseases Clinic. In this trial the TPHA, using Fuji-Zoki sheep cell antigen, was compared with four other tests: CWR, RPCF, VDRL, slide test, and FTA-ABS test. The results in Table I were obtained on the first 1,000 sera tested in this trial, and illustrate the great sensitivity of the FTAABS test and the TPHA in the detection of treponemal disease. Treponemal disease was detected in 334 individuals by the FTA-ABS test, in 261 individuals by the TPHA, and in 173 by the VDRL test. The RPCF test and CWR detected 155 and 141 cases of treponemal disease respectively.

TABLE I 1,000 patients with suspected treponemal disease tested in parallel by five procedures

\begin{tabular}{lll}
\hline Test & Number in whom treponemal disease was detected \\
${$\cline { 1 - 1 }$} }$ & 141 \\
RPCF & 155 \\
VDRL slide & 173 \\
TPHA & 261 \\
FTA-ABS & 334 \\
\hline
\end{tabular}

\section{(b) 15,000 unselected sera}

As a result of experience gained in the trial on clinic sera, it was decided to replace the complementfixation tests hitherto used in routine screening of all sera, namely the CWR and RPCF test, by a combination of the semiautomated micro-TPHA and the carbon antigen VDRL. Again, only Fuji-Zoki TPHA reagents were used at this stage. During the changeover, old and new procedures ran side by side for 9 days, and results on the 1,100 screened during this period are shown in Table II (i). Screening by CWR combined with the RPCF test brought to light 51 cases of treponemal disease (4.6 per cent.). However, when the same 1,100 sera were screened by TPHA alone, 86 cases of treponemal disease were detected ( $7 \cdot 8$ per cent.).
TABLE II Screening by TPHA compared with screening by $C W R$ and RPCF test

\begin{tabular}{|c|c|c|c|c|}
\hline Period & $\begin{array}{l}\text { No. of } \\
\text { sera } \\
\text { screened }\end{array}$ & $\begin{array}{l}\text { Screening test } \\
\text { used }\end{array}$ & $\begin{array}{l}\text { Cases of } \\
\text { treponemal } \\
\text { disease } \\
\text { detected }\end{array}$ & $\begin{array}{l}\text { Detection } \\
\text { rate } \\
\text { (per cent.) }\end{array}$ \\
\hline \multirow[t]{2}{*}{ (i) } & 1,100 & $\begin{array}{l}\text { (a) } \mathrm{CWR} \text { and } \\
\mathrm{RPCF}\end{array}$ & 51 & $4 \cdot 6$ \\
\hline & & (b) ТРНА & 86 & $7 \cdot 8$ \\
\hline (ii) & 15,000 & $\begin{array}{l}\text { TPHA and VDRL } \\
\text { TPHA alone }\end{array}$ & $\begin{array}{l}1,310 \\
1,289\end{array}$ & $\begin{array}{l}8 \cdot 7 \\
8 \cdot 6\end{array}$ \\
\hline
\end{tabular}

Table II (ii) shows results on 15,000 sera screened by the TPHA and VDRL test immediately after the changeover. Treponemal disease was detected in 8.6 per cent. by TPHA alone. The detection rate using the TPHA combined with the carbon antigen VDRL was only slightly higher (8.7 per cent.); however the VDRL gives useful information about activity of disease and effectiveness of treatment.

Table III gives details of the 35 patients in whom treponemal disease was detected by TPHA but not by CWR and the RPCF test (Table II $i$ ). They include one case of aortic valvular disease, and four patients referred from eye departments as diagnostic problems.

TABLE III 35 patients in whom antibody was detected by TPHA but not by CWR and RPCF test

\begin{tabular}{lcc}
\hline Diagnosis & No. of patients \\
\cline { 1 - 2 } Treated syphilis & 15 \\
From yaws areas & 11 \\
Referred from Eye Clinics & 4 \\
Aortic valvular disease & 4 \\
No information & \\
\hline Total & 35 \\
\hline
\end{tabular}

The high positivity rate on these unselected sera may be explained as follows: of the 30,000 specimens tested each year in this laboratory, half come from venereal diseases clinics; in addition, one-third of venereal disease clinic attenders, and probably a similar fraction of attenders at some of the other contributing clinics (e.g. antenatal) come from yaws areas.

\section{(c) 453 Ugandan sera}

Table IV shows results obtained on 453 Ugandan sera, using the semiautomated micro-TPHA technique and Fuji-Zoki reagents. These sera are of interest, as most of them contained antibody capable of agglutinating sheep erythrocytes to a titre of 1 in 128 or above. However, as the results show, heterophil antibody interfered very little with the test. Prevalence of heterophil agglutinins in a population is thus not a contraindication to the use of the TPHA. 
TABLE IV TPHA results on 453 Ugandan sera

\begin{tabular}{ll}
\hline Result & No. of sera \\
\hline TPHA negative & 262 \\
TPHA positive FTA-ABS positive & 190 \\
TPHA positive FTA-ABS negative & 0 \\
Interference by heterophil antibody & 1 \\
\hline Total & 453 \\
\hline
\end{tabular}

(d) 997 sera tested in parallel using two TPHA antigens 997 sera, 453 from Uganda and 544 of UK origin, were tested using reagents from two sources:

(i) Fuji-Zoki TPHA reagents consisting of $T$. pallidum-sensitized sheep erythrocytes and absorbing diluent (see reagents section);

(ii) Wellcome TPHA reagents, consisting of $T$. pallidum-sensitized turkey cells and a simple diluent. Tests comparing the two antigens were set up and read strictly in parallel. The results, shown in Table $\mathrm{V}$, were almost identical for the two antigens. There was very little interference with the tests due to antibodies directed against turkey erythrocytes, although the diluent used with the turkey cells contains no components designed to neutralize such antibodies.

TABLE V 997 sera tested in parallel using two TPHA antigens

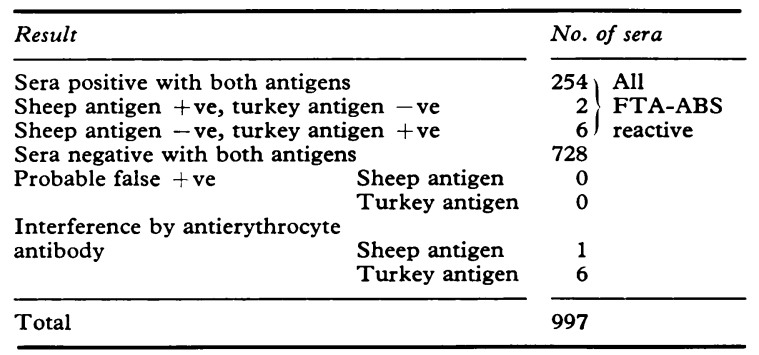

QUANTITATIVE TPHA RESULTS

All sera found to be TPHA-positive on screening were assayed quantitatively. Among the large number of patients with treponemal disease studied quantitatively were 105 patients with untreated syphilis (first attack) and 144 patients who had been treated for syphilis from 2 to 55 years previously.

\section{Untreated syphilis}

Table VI shows TPHA titres on patients with untreated syphilis. Re-infected patients are not included. The number of patients with late syphilis is small because we excluded those who might have had some treatment. It is clear that in syphilis TPHA antibody does not appear in significant amounts until the primary stage is well established. However, after that, it increases at a steady rate for some months, so that in early untreated syphilis the TPHA titre is a good guide to the duration of infection. Exceptions to this are patients with re-infections, in whom residual antibody from the earlier infection may complicate the picture.

TABLE VI TPHA reactivity in UNTREATED syphilis

\begin{tabular}{|c|c|c|c|c|}
\hline \multirow[t]{2}{*}{ Stage of syphilis } & \multicolumn{2}{|c|}{$\begin{array}{l}\text { Patients } \\
\text { TPHA-reactive }\end{array}$} & \multirow[t]{2}{*}{$\begin{array}{l}\text { Range of titres } \\
\text { (reciprocal) }\end{array}$} & \multirow[t]{2}{*}{$\begin{array}{l}\text { Typical titr } \\
\text { (reciprocal) }\end{array}$} \\
\hline & Per cent. & No. & & \\
\hline $\begin{array}{l}\text { Primary } \\
\text { Early secondary }\end{array}$ & $\begin{array}{r}66 \\
100\end{array}$ & $\begin{array}{l}52 \\
24\end{array}$ & $\begin{aligned}< & 80-320 \\
& 80-1,280\end{aligned}$ & $\begin{array}{r}80 \\
320\end{array}$ \\
\hline Late secondary & $\begin{array}{l}100 \\
100\end{array}$ & 7 & $\begin{array}{c}80-1,280 \\
1,280-82,000\end{array}$ & 5,120 \\
\hline Late latent & 100 & 11 & $80-5,120$ & - \\
\hline Late symptomatic & 100 & 9 & $1,280-160,000$ & $>5,120$ \\
\hline
\end{tabular}

In untreated late syphilis TPHA titres vary considerably. However, in our small group of twenty patients with late syphilis, very high titres ( 1 in 10,240 or above) were found only in patients with symptomatic disease (2 patients with aortic aneurysm, 1 patient with aortic incompetence, and 1 patient with a gumma of the frontal bone).

\section{Treated syphilis}

Data on patients with treated syphilis are shown in Tables VII and VIII. Table VII shows that TPHA reactivity, once acquired, is retained for many years.

TABLE VII TPHA reactivity in TREATED syphilis

\begin{tabular}{|c|c|c|c|c|c|}
\hline Years after treatment & 2 to 5 & 6 to 10 & 11 to 20 & $20+$ & Total \\
\hline $\begin{array}{l}\text { No. of patients tested } \\
\text { Percentage of patients }\end{array}$ & 47 & 29 & 20 & 48 & 144 \\
\hline still TPHA-reactive & 83 & 80 & 80 & 74 & - \\
\hline
\end{tabular}

TABLE VIII TPH.A titres after treatment for early syphilis

\begin{tabular}{|c|c|c|c|c|c|}
\hline \multirow{2}{*}{ Stage of syphilis } & \multirow{2}{*}{ No. of patients } & \multirow{2}{*}{ Years after treatment } & \multicolumn{3}{|l|}{ No. of patients } \\
\hline & & & Titre 1 in 80 & Titre 1 in 320 & Titre 1 in 1,280 \\
\hline Seropositive primary & $\begin{array}{r}14 \\
6 \\
5\end{array}$ & $\begin{array}{l}2 \text { to } 5 \\
6 \text { to } 20 \\
>20\end{array}$ & $\begin{array}{r}12 \\
4 \\
5\end{array}$ & $\begin{array}{l}2 \\
2 \\
0\end{array}$ & \\
\hline Secondary & $\begin{array}{r}13 \\
4 \\
3\end{array}$ & $\begin{array}{l}2 \text { to } 5 \\
6 \text { to } 20 \\
>20\end{array}$ & $\begin{array}{l}4 \\
2 \\
0\end{array}$ & $\begin{array}{l}7 \\
1 \\
2\end{array}$ & $\begin{array}{l}2 \\
1 \\
1\end{array}$ \\
\hline
\end{tabular}


Table VIII suggests that titres of TPHA antibody decline only very slowly after treatment, a conclusion which is also borne out by serial studies on patients (to be published). In this respect TPHA antibody resembles immobilizing antibody.

\section{SPECIFICITY OF THE TPHA}

Positive TPHA reactions in patients who do not have trefonemal disease appear to be very uncommon. We have come across four such patients in the course of this study, of whom three were chronic biological false positive (BFP) reactors. None of the four had immobilizing antibody or was FTA-ABS test reactive. Our data suggest a false positive rate of about 1 in 4,000 in a general hospital population.

\section{AGREEMENT WITH THE FTA-ABS TEST}

There were no occasions on which a patient known to have treponemal disease was reactive in the TPHA and non-reactive in the FTA-ABS test. However, one-third of patients with primary syphilis and a small proportion of those with treated syphilis were reactive by FTA-ABS test but non-reactive by TPHA. In addition, a number of patients with suspected treponemal disease, including a significant number of eye cases, were FTA-ABS test reactive but TPHA negative. We believe the TPHA to be slightly less sensitive than the FTA-ABS test.

\section{IMMUNOGLOBULIN CLASS OF ANTIBODY REACTING IN} THE TPHA

Thirty sera from patients with syphilis were titrated with and without 0.1 molar mercaptoethanol (ME) in the diluent (Claflin, Smithies, and Meyer, 1966). The sera chosen included specimens from patients at all stages of the disease. In no instance was there a diminution in titre observed after ME treatment of serum. This suggests that TPHA reactivity in human syphilis may be mediated principally by IgG class antibody, unlike the situation in experimental rabbit syphilis described by Okamoto and Tanabe (1971) in which IgM plays an important part. However further work is needed here.

\section{Summary and conclusions}

A micro-TPHA method suitable for use in the routine serodiagnosis of treponemal disease has been developed and evaluated on over 17,000 sera. The method has proved to be convenient and efficient.

Although less sensitive than the FTA-ABS test in very early syphilis, the performance of the TPHA in other categories of the disease is comparable to the
FTA-ABS test, and shows a degree of specificity and sensitivity far superior to the tests commonly used in the detection of treponemal disease, such as the CWR, and RPCF and VDRL tests.

Our experience is that the micro-TPHA is easier to perform than any screening test we have used up to the present time. One technician can screen up to 600 sera by TPHA and VDRL test, and quantitate them where necessary, during a single morning. Confirmatory FTA-ABS tests may be done, where indicated, in the afternoon of the same day. FTAABS tests may also be performed then, if desired, on sera from patients suspected of having primary syphilis, as these may be negative by the TPHA and VDRL test.

The incidence of false positives in TPHA screening is very low. In the rare instances in which a serum is TPHA positive but yields a negative result by the FTA-ABS test, a $T$. pallidum immobilization test should be performed.

At current prices, TPHA testing is relatively costly. However, economy in technician time represents a considerable hidden saving, and it is expected that costs of reagents will fall as the test becomes more widely used.

\section{References}

Claflin, A. J., Smithies, O., and Meyer, R. K. (1966) f. Immunol., 97, 693

Cox, P. M., Logan, L. C., and Norins, L. C. (1969) Appl. Microbiol., 18, 485

GaRnER, M. F., Backhouse, J. L., Daskalopoulos, G., and WALSH, J. L. (1972) Brit. F. vener. Dis., 48, 470

Johnston, N. A. (1972) Ibid., 48, 474

Logan, L. C., and Cox, P. M. (1970) Amer. F.clin. Path., 53, 163

Okamoto, S., and Tanabe, Y. (1971) Brit. F. vener. Dis., 47, 77

O’NeILl, P., and Johnson, G. D. (1971) Ann. N.Y. Acad. Sci., 177, 446

RATHLEV, T. (1965) W.H.O. VDT/RES/77.65

- (1967) Brit. F. vener. Dis., 43, 181

SEQUEIRA, P. (1973) Ibid., 49, 242

Tomizawa, T., and Kasamatsu, S. (1966) fap. f. med. Sci. Biol., 19, 305

,-- , and Yamaya, S. (1969) Ibid., 22, 341

Essai d'emploi en routine de l'hémagglutination du Treponema pallidum dans le diagnostic des tréponématoses

SOMMAIRE

Une microméthode TPHA utilisable pour le sérodiagnostic de routine des maladies tréponémiques a été mise au point et évaluée sur plus de 17.000 sérums. La méthode s'est montrée pratique et efficace. 
Quoique moins sensible que le test FTA-ABS dans la syphilis toute récente, le TPHA est comparable au test FTA-ABS dans les autres stades de la maladie et montre un degré de spécificité et de sensibilité de loin supérieur aux tests utilisés communément dans la détection des tréponématoses, tels le BW, le test RPCF ou le VDRL.

Notre expérience est que le microTPHA est plus facile à pratiquer qu'aucun des autres tests de dépistage que nous avons employés jusqu'ici. Un technicien peut, au cours d'une seule matinée, examiner jusqu'à 600 sérums par les tests TPHA et VDRL et faire l'étude quantitative lorsqu'elle est nécessaire. Des tests FTA-ABS de confirmation peuvent être faits si besoin dans l'après-midi du même jour. Les tests FTA-ABS peuvent aussi être faits alors, si on le désire, sur les sérums des malades suspects d'avoir une syphilis primaire, car ceux-ci peuvent être négatifs au TPHA et au VDRL. L'incidence de réactions faussement positives au dépistage TPHA est très basse. Dans les rares occasions où un sérum est positif au TPHA mais se montre négatif au FTA-ABS, un test d'immobilisation du $T$. pallidum doit être exécuté.

Aux prix actuels, les examens par les tests TPHA sont relativement coûteux. Cependant, l'économie sur le temps d'un technicien représente un gain considérable et on peut s'attendre à ce que le prix des réactifs diminue si le test est plus largement employé à l'avenir. 